\title{
Tracing temperature and oxygen isotope compositions of Early Triassic seawater with clumped isotope thermometry
}

\author{
T. VENNEMANN ${ }^{1 *}$, O. EDWARD ${ }^{1}$, Z. LUZ ${ }^{1}$, H. BUCHER ${ }^{2}$,
}

${ }^{1}$ Institute of Earth Surface Dynamics, University of Lausanne, Switzerland (*correspondence:

Torsten.Vennemann@unil.ch)

${ }^{2}$ Paläontologisches Institut der Universität Zürich, Zürich

Switzerland (hugo.fr.bucher@pim.uzh.ch)

Recent studies have demonstrated that precise clumped isotope measurements of well preserved carbonates allows primary and diagenetic processes that can influence the isotopic compositions of carbonates to be distinguished [1]. In contrast to measurements of $\delta^{18} \mathrm{O}$ only, clumped isotope compositions $\left(\Delta_{47}\right)$ may provide absolute temperatures of crystallisation independent of the isotopic composition of seawater. This study focusses on clumped isotope analyses of calcite from early to middle Dienerian abiotic micritic limestones intercalated within highly fossiliferous carbonates. These sediments were deposited on offshore seamounts and contain well-preserved fossils of nectic and benthic fauna [2]. Absolute $\Delta_{47}$-temperature estimates from three different micrites in two sections reproduce well (RAJ: $29 \pm 2.0^{\circ} \mathrm{C}$, $\mathrm{n}=3$; WAD2-MC: $47 \pm 3.5^{\circ} \mathrm{C}, \mathrm{n}=5$; WAD2-MP: $50 \pm 13^{\circ} \mathrm{C}$, $\mathrm{n}=4$; calibrated against ETH-1, -2 and -3 standards [3]). The $\delta^{13} \mathrm{C}$ (VPDB) and $\delta^{18} \mathrm{O}$ (VSMOW) values are also homogeneous (RAJ: $\delta^{13} \mathrm{C}$ of $+2.4 \pm 0.1 \%$, $\delta^{18} \mathrm{O}$ of 30.5 $\pm 0.2 \%$; WAD2-MC: $\delta^{13} \mathrm{C}$ of $+2.0 \pm 0.4 \%, \delta^{18} \mathrm{O}$ of 28.9 $\pm 0.3 \%$; WAD2-MP: $\delta^{13} \mathrm{C}$ of $+1.4 \pm 0.3 \%$, $\delta^{18} \mathrm{O}$ of 27.7 $\pm 0.1 \%$ o). Clumped isotope thermometry hence supports Dienerian Neothethys subequatorial seawater temperatures within the range for the modern sea surface $\left(25\right.$ to $\left.32^{\circ} \mathrm{C}\right)$. Calculated seawater $\delta^{18} \mathrm{O}$ for the likely well-preserved RAJ section are between $-0.4 \%$ and $+2.3 \%$, similar to the range of modern, evaporated sea-surface waters in subtropical oceans. The large range and higher average temperatures for the WAD sections at lower $\delta^{18} \mathrm{O}$ for carbonates also give higher $\delta^{18}$ OWater, likely due to diagenetic alteration in a rockbuffered system in the presence of seawater.

[1] Bergmann et al. (2018) Geochimica et Cosmochimica Acta 224, 18-41. [2] Souquet and Goudemand (2019) Palaeogeography, Palaeoclimatology, Palaeoecology in press [3] Bernasconi, Stefano M., et al. (2018) Geochemistry, Geophysics, Geosystems 19.9, 2895-2914. 